\title{
Challenges of Teaching Chinese as a Subject in an English-Dominated Region: Focus on Sindh, Pakistan
}

\author{
Ameer Ali \\ IELL, University of Sindh, Jamshoro, Pakistan \\ Maya Khemlani David \\ AEI, University of Malaya, Kuala Lumpur, Malaysia
}

\begin{abstract}
Sindh is a multilingual province in Pakistan where politics of language and clash of language ideologies have played a significant role. English is viewed as a language of power, and Urdu is generally considered as a symbol of national cohesion in Pakistan. In Sindh both these languages are used in official and educational domains In Sindh's language ecology, English occupies an important position. In addition to these two languages, Sindhi is widely spoken and is associated with Sindh's regional and ethnic consciousness. Pakistan's pivot to China policy is slowly impacting language policy and planning in Sindh. Politicians have started talking about making Chinese a compulsory subject from grade 6 onwards in Sindh's educational institutions. However, this language policy decision has met resistance from the English-speaking class, and the Urdu, Seraiki, and Sindhi speech communities who look at the imposition of Chinese language with distrust. The aim of this research article is to investigate how language teachers and students in Sindh react to the Chinese language policy and planning. A survey questionnaire was sent to participants to explore their perceptions of imposing the Chinese language in Sindh. 33 participants aged between 20 to 40 responded to 14 questions included in the survey. Extracts taken from their responses were codified into broader themes and qualitative analysis was carried out using Philipson's (1992) imperialism concept. The findings showed that the pro-Chinese class is struggling to replace English in an ecology of language where speakers of minor languages are already resisting the hegemony of major languages.
\end{abstract}

Key words: $\quad$ Chinese; English; Languages; Sindhi; Urdu

\section{Introduction}

This research takes place against the backdrop of an increasing body of scholarship on linguistic imperialism and the Chinese language (He, 2013; Uyghur Human Rights Project Report, 2019). Some researchers have also traced the intersection between China's rise through Belt and Road Initiative (BRI) and linguistic imperialism (Sparks, 2014; Sparks, 2018; Gao, 2020; Melvin, 2020), while other researchers have associated the China Pakistan Economic Corridor (CPEC) with the expansion of Chinese neo-imperialism in Pakistan (Ejaz and Masood, 2019). Against the backdrop of CPEC, the teaching of Chinese as a subject in Sindh province is seen as a manifestation of linguistic imperialism. This research manifests the operation of linguistic imperialism in Pakistan's Sindh province where the Pakistani government has been trying to impose the Chinese language in all schools from class six onwards (Dawn, 2015). This paper deploys "linguistic imperialism" as a conceptual analysis for conducting analysis of the data. Many researchers (Sparks, 2014; Paradise, 2009; Liu, 2019) have used this conceptual framework in a wide range of contexts to demonstrate how language of a more powerful group/state marginalizes language of a weaker group/state.

\section{II.linguistic imperialism}

The concept of linguistic imperialism was popularized by Philipson in 1992 who defined it as direct control by a state/group over another state's language planning and policy. The concept of linguistic imperialism has evolved over time. Currently, the compound word 'neo-imperialism' is used to refer to how a state exerts influence over another state economically, politically, culturally, and linguistically. Some states may surrender their language policy and planning to a more powerful state because of the former's economic reliance over the latter. Countries with low GDP are more prone to accepting a foreign country's (with high GDP) language and culture, because their wellbeing is associated with maintaining good relations with the latter. Within this conceptual framework, this research seeks to address if the teaching of Chinese as a subject, is seen as linguistic imperialism, and if it is perceived as posing challenges to Sindh's regional languages and language policy and planning, causing linguistic resistance from different language groups, 


\section{Yinternational Resoarch Jourma}

p-ISSN 2202-2821 e-ISSN 1839-6518 (Australian ISSN Agency)

such as the English-speaking groups, and the activists of Urdu, Sindhi, and other regional languages.

In the context of this study, the policy recommendation of teaching Chinese as a subject in schools in Sindh is conceptualized as a manifestation of linguistic imperialism. Thus, linguistic imperialism and linguistic resistance is seen at the heart of this analysis. We discuss how local language groups and English-speaking groups are resisting the language policy recommendation of teaching Chinese in all schools of Sindh from grade 6 onwards. We argue that teaching Chinese as a subject is not an apolitical decision, rather it is a part of Pakistan's pivot to China.

In the following section, the teaching of the Chinese language is contextualized against the background of the multilingual landscape of Pakistan's Sindh province.

\section{A. Contextualizing the Teaching of Chinese and its inroads in Pakistan's Sindh Province}

The Chinese government has been encouraging the teaching of Chinese as a foreign or second language since 1970s (Wenfeng and Gao, 2008; Gong, Lai, and Gao, 2020; Gong, Gao, and Lyu, 2020). Over the last two decades, Chinese has been increasingly taught and learnt as a foreign or second language both inside and outside China and is driven by government investment (Zhao and Huang, 2010). On $27^{\text {th }}$ December 2014, the Confucius Institute, a symbol of China's soft power and an extension of its economic power, celebrated its $10^{\text {th }}$ anniversary and initiated the first Confucius Institute Day. "The Chinese Language Council International (often referred to as Hanban) also launched the first series of HSK (Hanyu Shuiping Kaoshi, the official, standardized Chinese proficiency test) Standard course books 2014" (Gong, Gao, and Lyu, 2020: 44). In December 2018, 548 Confucius Institutes and 1,193 classrooms had been established for teaching Chinese to more than 1.1 million students in 146 countries across the world (Hanban, 2019).

The growth of Chinese as a foreign or second language teaching or learning has been linked with intensive research on critical issues regarding the teaching of Chinese to nonChinese learners worldwide (Gong, Gao, and Lyu, 2020). Since the late 1970s, research on teaching and learning Chinese as a foreign language has steadily increased (Zhao and Huang, 2010; Baralt and Bravo, 2016; Jiang and Cohen, 2012; Conti and Lepadat, 2021). Since the last fifteen years, the growth has been both multidimensional and noteworthy (Gong, Gao, and Lyu, 2020). Similarly, teaching of the Chinese language made inroads into Sindh in 2015 when the Government of Sindh signed a memorandum of understanding with the Chinese government and the teaching Chinese was
Vol. 12 No. 012022

828012012022182 (C) Author(s)

made compulsory from grade 6 upwards in schools in Sindh (Dawn, 2015).

Due to the memorandum of understanding and the language policy decision, we conducted a qualitative investigation of the perception of different language groups to the teaching of the Chinese language in Sindh, a multilingual, multiethnic province (for details see Ali and David, 2021). These groups include the Sindhis, Urdu speaking groups, the Seraikis and others. Imposing the teaching of the Chinese language in such a multilingual province where politics of language has been normal can be challenging (Ali and David, 2021). We invited participants from different language groups to participate in an open/close ended survey questionnaire made using Google Forms. The aim was to determine their responses to the policy of teaching Chinese in Sindh's schools. The responses which we received are consistent with views of activists in a wide range of contexts where linguistic imperialism has been a socio-political norm (Smith and Donghwan, 2015; Reeves, 2018; Alexis-Martin, 2019; Qingpu, 2019).

\section{B. Language Policy, Linguistic Imperialism, and Challenges to Teaching Chinese as a Subject}

Some researchers have shown how China is promoting linguistic and cultural imperialism and soft image through Confucius Institutes around the world (Xie, 2014; Paradise, 2009; Liu, 2019). Linguistic imperialism is conceptualized as the imposition of one language on speakers of other languages (Philipson, 1992; Canagarajah and Said, 2016); and is also called linguistic dominance, or linguistic nationalism (Nordquist, 2019). In this study, we focus on how the teaching of Chinese as a subject in Sindh affects English and other local languages, how the anglicized class and local language groups respond to it, and how language policy and planning is influenced by Chinese linguistic imperialism.

Local languages of Sindh and other provinces of Pakistan (Khyber Pakhtunkhwa, Baluchistan, and the Punjab) have not received due focus and investment; and none of the local languages except Urdu has been recognized as a national language in Pakistan (for details see Ali and David, 2021). English, a foreign, colonial language, has always remained a language of prestige and status in Pakistan (Manan, David, and Dumanig, 2016; Manan, 2021). Some sources also claim that Pakistani students are keen to learn the Chinese language (see Xinhua, 2019).

The obsession with teaching and learning foreign languages has characterized Pakistan's language policy and planning while local languages have been neglected. According to Pakistan's foreign ambassador to the United States, Husain Haqqani, "In a short span of 70 years, Pakistan has flirted with 


\section{Yinternational Research Journa}

p-ISSN 2202-2821 e-ISSN 1839-6518 (Australian ISSN Agency)

promoting four languages that were not the mother tongue of many people in the country-English, Urdu, Arabic, \& now Chinese-ignoring local languages" (Jakhar, 2018). Some researchers have investigated linguistic imperialism and obsession in Pakistan's context (Jabeen, 2020; Naqvi, 2017; Durrani, 2012; Ali, 2021). Employing linguistic imperialism as a theoretical lens, these researchers examined how foreign languages have resulted in the neglect of the teaching of local languages. Foreign languages have been associated with prestige and status, whereas local languages have been deemed inferior and unsophisticated.

\section{Methodology}

This research was designed to investigate the provincial government's decision/recommendation of teaching Chinese as a subject in Sindh, and how local language groups responded to this decision/recommendation. The research sites were both rural and urban areas of Sindh, a province in Pakistan (see Graph 1).

\section{Graph 1: Research Sites}

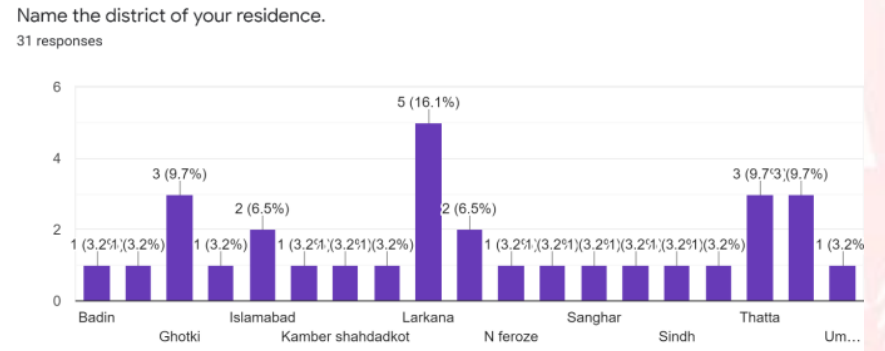

The research was conducted between May and June 2021. The research employed Google survey form as research tool which contained both open-ended and close-ended questions. In total, there were 14 questions which were sent through Gmail, WhatsApp, and Facebook Messenger to different language groups living in Sindh (see Graph 2). No face-toface interviews were possible due to physical restrictions imposed by the state government during the era of the covid pandemic.

33 participants belonging to the Sindhi, Urdu, and Seraiki communities and associated with teaching/learning languages took part in this research and shared their views. Different speech communities were involved in this research so that their responses towards the imposition of the Chinese language in Sindh's schools could be elicited. Most of the participants who took part in this research are either language/linguistics teachers or language/linguistics students. These were selected using probability sampling because their fields and careers are related to languages, linguistics, and language policy.
Vol. 12 No. 012022

\section{Graph 2: Mother Tongue of Participants:}

What is your mother tongue?

32 responses

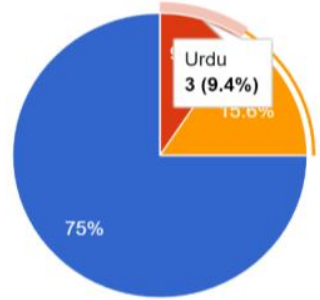

Sindhi

Urdu

Seraiki

Punjabi

Brahui

or other

The Google survey questions were written in English. Furthermore, close-ended, and open-ended questions were tactically used to encourage participants to elaborate on a topic or idea. It was also ensured that ethical protocols were followed while collecting data from the participants. We sought their consent to use their data and guaranteed their confidentiality. In the analysis phase, the Google Forms were converted into spreadsheets and relevant extracts, statistics, and diagrams were purposively taken to conduct analysis using the concept of linguistic imperialism. Data organization, transcription, and coding were conducted to identify the central ideas and patterns.

Participants were mostly men (27) with 6 women as in a male dominated society most men were willing to share their views. They were mostly multilinguals speaking 3 to 4 languages and aged between 20 to 50 (see Graph 3).

\section{Graph 3: Multilingual Reality of Participants}

\section{How many languages can you speak?}

32 responses
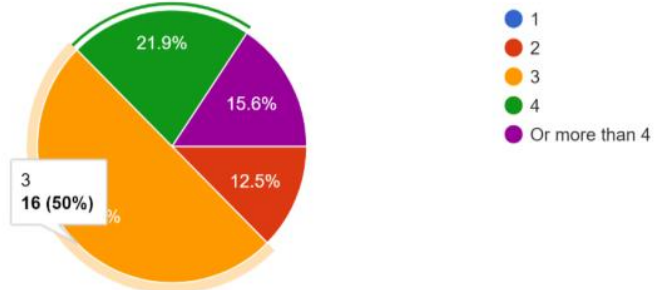

Most of the participants were graduates and some of them were enrolled in a postgraduate course or working as language teachers.

\section{Findings}

In this section, findings are discussed in the following themes: Effects of Teaching Chinese on English Language Learning in Sindh; Effects of Teaching Chinese on Local Languages, and Teaching Chinese as a Subject: Linguistic Imperialism?

Before moving to the sections on analysis we summarize research findings here in Table 1.

Table 1: Quantifying Research Findings 


\begin{tabular}{|c|c|}
\hline Participants & $\begin{array}{l}\text { Percentage of } \\
\text { Participants }\end{array}$ \\
\hline $\begin{array}{l}\text { 1. Participants who opposed Chinese } \\
\text { as a subject in Sindh. }\end{array}$ & $68.8 \%$ \\
\hline $\begin{array}{l}\text { 2. Participants who saw imposing } \\
\text { Chinese as a form of linguistic } \\
\text { imperialism. }\end{array}$ & $69 \%$ \\
\hline $\begin{array}{l}\text { 3. Participants who claimed Chinese } \\
\text { will have no effects on English } \\
\text { dominance in Sindh. }\end{array}$ & $10 \%$ \\
\hline $\begin{array}{l}\text { 4. Participants who thought Chinese } \\
\text { would marginalize the local } \\
\text { languages. }\end{array}$ & $69 \%$ \\
\hline $\begin{array}{l}\text { 5. Participants who believed } \\
\text { Introducing Chinese in Sindh } \\
\text { would lead to cultural, linguistic } \\
\text { hybridization. }\end{array}$ & $15 \%$ \\
\hline $\begin{array}{l}\text { 6. Participants who claimed Chinese } \\
\text { will have no effects on the local } \\
\text { languages }\end{array}$ & $10 \%$ \\
\hline
\end{tabular}

Now, research findings based on the above given headings and statistics are analyzed and discussed.

Effects of Teaching Chinese on English Learning in Sindh

Participants from English speaking class were asked about the repercussions of imposing the Chinese language as a subject in Sindh's schools. It was important to know their views, and to establish how the concept of linguistic imperialism affects their subjectivities about the learning of the Chinese language. The analysis shows a range of factors that prohibit them from learning Chinese. Here, we present some prominent factors that were repeatedly voiced by the participants. There is resistance from the Anglicized class against the imposition of Chinese due to the following reasons:

- The English language has comparatively greater linguistic value.

- Linguistic dominance of English- English is the lingua franca and official language in over 60 countries.

- The Chinese language is more difficult to learn as compared to English.

We note that 2 participants believe that teaching Chinese in Sindh would be difficult because students and parents prioritize English over other foreign languages. For instance, a participant said: "English has been a legacy of colonialism in Sindh and Pakistan. Chinese as a language cannot completely subdue English. Chinese would remain a foreign language just taught in schools. It would never replace English in public domains". Another participant argued, "replacing one colonizer and its culture with the other is not a smooth task. It will affect the understanding of English in official documentations".

In contrast, 7 participants responded that Chinese will gradually replace English in Sindh and Pakistan. One of the participants expressed his views: "given the situation, the next dominant nation is China, learning their language can give certain opportunities in securing jobs". Their responses are summarized and listed here:

- The Chinese language would resist English dominance.

- Chinese as a language of an emerging nation would provide more job opportunities.

- There will be increasing importance of the Chinese language in Sindh and Pakistan due to CPEC (China Pakistan Economic Corridor).

- The Chinese language could be an alternative to English.

- There will be glocalization of Chinese in Sindh and Pakistan.

- Learning Chinese means learning a new culture.

- China is a new world power spreading her linguistic dominance.

This list demonstrates the view of the respondents that the Chinese language will gradually claim dominance in Sindh and Pakistan replacing English. Participants suggest that learning Chinese will open their windows to Chinese job markets. One participant says "Chinese will change the course of dominance of English in Pakistan. People will know about new culture and language". Another participant said "China is just not going to be a regional power, but it's also going to be a world power. So, she will do her best to spread her linguistic dominance".

There were still 4 participants who were of the view that it would be a win-win situation for both the Chinese language and the English language in Sindh and Pakistan. They said that the English language would retain its own place, while the Chinese language will make its own place in new settings. One participant suggested, "Chinese language can take its own place without much affecting English which would retain its importance and place in Pakistan and Sindh".

Furthermore, there were some participants (about 10\%) who claimed that teaching Chinese as a subject will have no longterm serious effects on English. They asserted that most educated Pakistanis are deeply affected by Western influence. 


\section{Yinternational Resoarch Jourma}

p-ISSN 2202-2821 e-ISSN 1839-6518 (Australian ISSN Agency)

For instance, one of the participants said, "Till some time, Chinese won't have any effect...because Pakistanis mostly prefer western countries, and they have a mindset to establish themselves in those countries...". Effects of Teaching Chinese on Local Languages

The participants were also asked how imposing Chinese as a subject can affect local languages in Sindh. More than $85 \%$ of the participants said that Chinese would indeed affect local languages in different ways. Their responses are summarized in Table 2.

Table 2: Effects of Teaching Chinese on Local Languages

\begin{tabular}{|c|c|c|}
\hline Question & Response Category 1 & Response Category 2 \\
\hline $\begin{array}{l}\text { How do you } \\
\text { think the Chinese } \\
\text { language will } \\
\text { affect the local } \\
\text { languages of } \\
\text { Sindh? }\end{array}$ & $\begin{array}{l}\begin{array}{l}\text { Linguistic Marginalization } \\
\text { (key terms from responses) }\end{array} \\
\text { - Victimization of the Sindhi } \\
\text { language Chinese } \\
\text { influence on language } \\
\text { policy will pose a threat to } \\
\text { Sindh's local languages } \\
\text { and literature } \\
\text { - Linguistic burden on } \\
\text { students } \\
\text { - Linguistic and cultural } \\
\text { invasion }\end{array}$ & $\begin{array}{l}\text { Glocalization of } \\
\text { Chinese/mutual } \\
\text { linguistic influence } \\
\text { (key terms from } \\
\text { responses) } \\
\text { - Impacting diction } \\
\text { and everyday } \\
\text { vocabulary of the } \\
\text { Sindhi language. } \\
\text { - Borrowing words } \\
\text { from Chinese } \\
\text { - Creating mixed } \\
\text { lingual culture } \\
\text { - Glocalization of } \\
\text { Chinese with } \\
\text { Sindhi, Urdu, and } \\
\text { English influence }\end{array}$ \\
\hline
\end{tabular}

22 participants were of the view that teaching of Chinese will cause marginalization and discrimination against the local languages of Sindh (see Table 3).

The responses in Table 3 demonstrate how dominant, foreign languages have marginalized minor local languages over the course of the history of linguistic dominance. One of the responses revealed that Sindh's local languages are under the threat of disappearance due to the Sindh government's decision to teach Chinese as a compulsory subject from grade 6 onwards. In this regard, a participant added, "replacing one colonizer and its culture with another colonizer is not a smooth task...". Hence, imposing Chinese as a subject is equated to linguistic dominance which, according to one of the participants, is marginalizing the local languages.

The participants believe that their native languages have enjoyed prestige and status throughout history, however, the onslaught of foreign nations, such as the Arabs, the Persians, the English, and others has scarred the native languages. Similarly, Sindh government's decision of 2015 to impose Chinese as a subject in Sindh is seen as a chain of the colonial,
Vol. 12 No 012022 828012012022182 (C) Author(s)

linguistic assault. One of the participants called it 'cultural invasion'. This onslaught is said to affect the native Sindhi language and its dialects in Sindh.

The participants' responses also indicate probable influence of Chinese on language policy and planning in Sindh and Pakistan. For example, a participant added, "Tendency towards learning the foreign language (Chinese) would definitely be given importance, and local languages will be neglected in language policy and planning". 69\% participants confidently asserted that the pro-Chinese tendency in Sindh, and Pakistan's language policy and planning would gain momentum, and eventually the local languages would hardly be offered any space. This probable negligence of the local languages has been looked upon as an act of pushing the local languages to the peripheries marginalizing their narratives and culture. This selective discrimination against the local languages has been termed by one participant as a 'biased' approach in language policy and planning. The participants' understanding of the impact of increasing Chinese influence in Sindh and Pakistan appears to be informed by Philipson's (1992) concept of linguistic imperialism which means imposing one language on the speakers of other language/s.

\section{Table 3: Statements depicting fear of} losing local languages

1. "as per study, slowly many languages are disappearing from the world due to the influence of foreign languages. Sindh's local languages are also under threat. In urban Sindh, Sindh's local languages are already replaced by Urdu and English. So, introducing the Chinese language will further affect Sindh's local languages across Sindh"

2."over the ages, Arabic, Persian, Urdu and English greatly affected the prestigious power of the Sindhi language. Similarly, state's decision to teach Chinese might damage the Sindhi language and its dialects. Sindhi Linguists must come forward to preemptively plan to avoid any such damage to the indigenous roots".

3. "Tendency towards learning the foreign language (Chinese) would definitely be given importance, and local languages will be neglected in language policy and planning"

4. "the local languages have already been treated as peripheries and are badly discriminated. The language policy in Pakistan has remained biased as far as ethnic and national diversity is concerned. Chinese will be another blow to the development of the local languages".

Furthermore, there were some participants (about 10\%) who claimed that teaching Chinese as a subject will have no long- 


\section{Yinternational Research Journal}

p-ISSN 2202-2821 e-ISSN 1839-6518 (Australian ISSN Agency)

term serious effects on local languages (see Table 4). They believe that even if the Chinese is introduced as a subject, people will continue to use their mother languages in their homes and daily lives. Moreover, one of the participants (see response 2 in Table 4) argued that Sindh's people are deeply attached with their languages, so this cannot affect their languages or culture.

\section{Table 4: No negative effects of Imposing the Chinese Language}

1. "this will not affect our regional languages because still the people will use their mother tongue in their lives and homes".

2. "the impacts would not be serious and notable vis a vis Sindh's local languages because these languages are deeply ingrained in our society and cultures. We cannot talk Chinese at our homes, and it cannot replace our mother tongues...'

There were $15 \%$ participants who believed that introducing Chinese in Sindh would pave the way for hybridization of language and culture (see Table 5 for the participants' responses).

\section{Table 5: Depicting Hybridization}

\section{1. "...create a mixed lingual culture"}

2. “...people will start borrowing words from Chinese, as they did in the case of English"

3. "...there will be a new language that would be English, Urdu, Sindhi, and Chinese mixture".

Table 5 summarizes the participants' responses () regarding the hybridization process, possibly emerging after linguistic encounter between the dominant Chinese language and the local languages. $15 \%$ participants expressed the possible reality that the linguistic encounter will bring about "a mixed culture" in Sindh's context (see statement 1 in Table 5). This indicates both the probable glocalization of the Chinese language and hybridization process. Additionally, the hybridization process will be characterized by the two-way borrowing of lexical items, which will result in a new linguistic mixture (see response 2 in Table 5). This linguistic hybridity, it was claimed, will contain linguistic elements from the local languages and the Chinese language. These responses from the participants appear to be informed by Acheraïou's (2011) concept of hybridity. Acheraïou (2011) argues that hybridity is brought about when the colonizers and the colonized create a third space of social interaction, and this has been used to maintain inequalities. Similarly, linguistic hybridization between Chinese and the local languages will create linguistic inequalities with the former playing a more dominant role.
Vol. 12 No. 012022

828012012022182 (C) Author(s)

Thus, different participants gave different responses, and 69\% participants saw introducing Chinese in Sindh as a manifestation of linguistic imperialism. We move on to discuss what linguistic hegemony means to the participants and how it applies to the imposition of the Chinese language in Sindh.

Teaching Chinese as a Subject: Linguistic Imperialism.

Due to the China Pakistan Economic Corridor (CPEC), the concept of linguistic imperialism has become more relevant in Sindh and Pakistan's context (see Table 6 for the participants' responses).

\section{Table 6: Statements suggesting Linguistic Imperialism}

1. "it would cause double colonization, and the local languages will suffer"

2. "Chinese influence is indeed growing in Pakistan, and this may have effects on Pakistan's policies. Policies including language policies will be made to please the Chinese".

3. "I think that the Chinese influence is growing due to CPEC, and this will make Pakistan more dependent on China"

4. "There will be dire consequences; elimination of local languages by enforcing Chinese language, economic exploitation, and threat to rich social-cultural system of Pakistan".

5. "Chinese influence will grow in Pakistan because Chinese investment in Pakistan will increase. Culturally, and linguistically, this region will be influenced by Chinese culture".

6. "Sino-influence is rapidly growing in Pakistan. There are also interracial marriages. Pakistani students are going to China for studies, and they come back with Chinese ideas and speak Chinese. This is a new educated class rapidly emerging in Pakistan”.

7. "It is the idea of ruling bloc to not only impose their culture and values but also their language as a ruling language. Like English and Urdu are imperialist languages in Pakistan. Coming of Chinese will be another brand of imperialist language in Pakistan. That's the peculiarity as far as the colonial state reality of Pakistan is concerned."

8. "Throughout history, nations with strong economic power have always ruled the world with their mother tongue being the trade language. Traders have always influenced the nation's financial power, and their language becomes important for other nations to learn in order to do business. Previous historical examples are of French, Arabic, Persian, and English languages that they almost ruled the entire world. Now, the Chinese are inheriting the colonial roles".

Under the increasing Chinese influence, the linguistic policy and planning is likely to be modified and changed. The 


\section{Yinternational Research Journal}

p-ISSN 2202-2821 e-ISSN 1839-6518 (Australian ISSN Agency)

participants' responses (more than 69\%) typify the understanding of linguistic supremacy, and resistance to it. The participants' definition of linguistic imperialism suggest that linguistic dominance manifests itself in linguistic dominance of a language group over another language group or groups. For instance, a participant defined linguistic hegemony, "it is a phenomenon of a powerful language group imposing its language on a weaker language group". Similarly, another participant defined it, "linguistic imperialism means enforcement of foreign language on other people".

The general idea that is noted from the responses of the participants demonstrates that the imposition of the Chinese language in schools would gradually cause 'double colonization' of the local languages, literatures, and cultures. Moreover, 69\% participants viewed the decision to impose Chinese as an example of linguistic colonialism, which demonstrates their passive resistance against Chinese hegemony (see Graph 4).

\section{Graph 4: Linguistic Imperialism}

Do you think imposing Chinese in Sindh is a form of linguistic imperialism? 33 responses
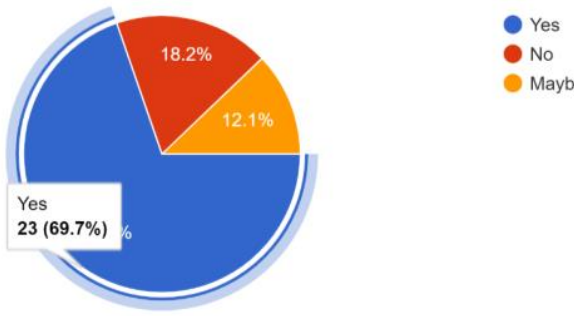

Maybe

Consequently, most of the participants did not endorse the decision of teaching Chinese as a subject in Sindh's schools (see Graph 5).

\section{Graph 5: Lack of Support for the teaching of the Chinese language}

Do you support Chinese become a compulsory subject in schools in Sindh? 32 responses
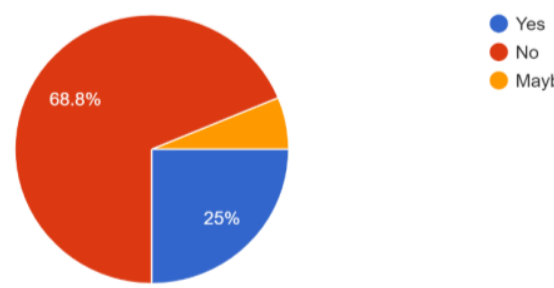

Maybe

Another idea that emerged from the participants" responses dealt with how the increasing influence of the Chinese and their language is going to affect the language policy and planning in Sindh and Pakistan. It was mentioned in one of the responses that the authority of policy making would be put at
Vol. 12 No. 012022

828012012022182 (C) Author(s)

the disposal of the Chinese and attempts would be made to make such language policies satisfy the Chinese and serve their sociolinguistic interests. The participants' responses linked the increasing influence of the Chinese language with the bilateral project China Pakistan Economic Corridor (CPEC). Furthermore, their responses suggest that they believed that the increasing influence of the Chinese language would lead to linguistic suppression of the minority language groups, their socio-cultural diversity, and their socio-economic exploitation.

The participants' answers also showed the multifaceted reality of Chinese imperialism. Increasing Chinese influence is characterized by cultural hegemony, economic supremacy, and linguistic dominance. Their responses revealed that the colonizer/imperialist power always promotes its language as a language of trade and commerce, thereby convincing the colonized/minor language groups of their linguistic inferiority.

These responses not only demonstrate the opinions the participants have about the Chinese language but also depict how their understanding of linguistic dominance governs their perceptions towards the increasing Chinese influence. As Philipson (1992) postulates, linguistic dominance involves one language group overpowering another language group. An analysis of linguistic hegemony needs to address what constitutes social reality and experience from the viewpoint of the layman.

Hence, a central idea that comes from the discourses of the participants is that the Chinese linguistic onslaught in the wake of CPEC appears to govern language management, language policies and practices, and culture. The participants demonstrate how they view the decision of teaching Chinese and see it as a new form of linguistic imperialism. They also see it as a cultural invasion that can put Sindh and Pakistan's local languages and cultures at risk.

\section{Conclusion : A Critical Summation}

In the words of Canagarajah and Said (2016: 391), "linguistic imperialism (LI) refers to the imposition of a language on other languages and communities". This study has demonstrated that discourses and actions regarding language dominance, language policies, or foreign language teaching are deeply intertwined with the core principles of linguistic imperialism. The responses and understanding shared against the teaching of Chinese as a compulsory subject in Sindh are closely interwoven with the critical understanding of linguistic imperialism.

As language is social capital Chinese linguistic imperialism in Sindh is evidently also driven and activated by the Sindh government's desire for people to learn more and more 
Chinese so that Pakistanis gain linguistic skills and stay competitive in a Chinese-dominated linguistic market. It should be mentioned that $18 \%$ of the participants said that the teaching of Chinese will neither affect the English language nor the local languages. This will also enable the ruling elites of Sindh and Pakistan to reap benefits from CPEC. The fear of being unemployed and linguistically deficient in the Chinese language consumes some participants, and they are constantly under pressure to improve themselves and fulfill the demands of the market (see also Shin and Park, 2016).

However, the study shows that participants, both three local language groups and English-speaking class in Sindh view the increasing influence of the Chinese language with suspicion and see it as linguistic imperialism. In the view of scholars, such as Reeves (2018) China deploys imperialist means to achieve its desired, regional order.

The study shows that most of the participants (69.7\%) saw the introduction of the Chinese language in Sindh as linguistic imperialism, causing hybridization in future, although there are a small minority (18\%) who claimed that teaching the Chinese language as a subject will not cause any serious consequences for local languages and cultures. To sum up, the study concludes that linguistic imperialism offers a useful theoretical lens to examine the nuances of linguistic dominance that control language policy, language practices and marginalize minor languages in general. This theoretical lens is hoped will guide researchers to expand research in different contexts. However, we need to conduct a larger study of participants, not only in Sindh but also in other regions in Pakistan, to determine if the introduction of the Chinese language is viewed by Pakistanis- as linguistic imperialism or as an opportunity to be gainfully employed.

\section{References}

[1]. Acheraïou, A. (2011). Questioning hybridity, Postcolonialism and globalization. Springer.

[2]. Alexis-Martin, B. (2019). The nuclear imperialismnecropolitics nexus: Contextualizing Chinese-Uyghur oppression in our nuclear age. Eurasian Geography and 6conomics, 60(2), 152-176. https://doi.org/10.1080/15387216.2019.1645611

[3]. Ali, A., \& David, M. K. (2021). A historical institutionalism approach to the politics of languages of Pakistan. Journal of Humanities and Social Sciences Research, 3(1), 75-90. https://doi.org/10.37534/bp.jhssr.2021.v3.n1.id1086.p75

[4]. Ali, Z. (2021). Becoming an English teacher in postcolonial Pakistan and Australian classrooms: Negotiating difference in postcolonial settings. Changing English, 28(1), 45-57. https://doi.org/10.1080/1358684x.2020.1815521
[5]. Baogang, H. (2013). The power of Chinese linguistic imperialism and its challenge to multicultural education. Minority Education in China, 45-64. https://doi.org/10.5790/hongkong/9789888208135.00 3.0003

[6]. Baralt, M., \& Bravo, M. L. (2016). Teaching Chinese as a foreign language: A classroom study on the timing of grammar around a task. Chinese as a Second Language Research, 5(1), 27-61. https://doi.org/10.1515/caslar-2016-0002

[7]. Canagarajah, S., \& Said, S. B. (2016). Linguistic Imperialism. In The Routledge Handbook of Applied Linguistics. Routledge.

[8]. Conti, S., \& Lepadat, C. (2021). Situation-bound utterances in Chinese as a foreign language: The effectiveness of the identification task. Chinese as a Second Language Research, 10(1), 1-29. https://doi.org/10.1515/caslar-2021-0001

[9]. David, M. K. and Saeipoor, N. (2018) "Integrating Soft Skills into Courses in Malaysian Public Universities: (Undergraduatesâ€ $€^{\mathrm{TM}}$ Perception)", IARS' International Research Journal. Victoria, Australia, 8(1). doi: 10.51611/iars.irj.v8i1.2018.83.

[10]. Dawn. (2015, March 25). Accord signed to teach Chinese in Sindh schools. DAWN.COM. https://www.dawn.com/news/1171645/accord-signedto-teach-chinese-in-sindh-schools

[11]. Durrani, M. (2012). Banishing Colonial Specters: Language Ideology and Education Policy in Pakistan. 27 (1), Retrieved from https://repository.upenn.edu/wpel/vol27/iss1/3.

[12]. Ejaz, K., \& Masood, M. (2019). Neo-imperialism: a case study of China Pakistan economic corridor. Journal of Politics and International Studies, 5(1), 8596.

[13]. Gao, Y. (2020). undefined. Sustainability, 12(14), 5506. https://doi.org/10.3390/su12145506

[14]. Gong, Y., Gao, X., \& Lyu, B. (2020). Teaching Chinese as a second or foreign language to nonChinese learners in Mainland China (2014-2018). Language Teaching, 53(1), 44-62. https://doi.org/10.1017/s0261444819000387

[15]. Gong, Y., Lai, C., \& Gao, X. (2020). The teaching and learning of Chinese as a second or foreign language: The current situation and future directions. Frontiers of Education in China, 15(1), 1-13. https://doi.org/10.1007/s11516-020-0001-0

[16]. Hanban [Confucius Institute (2019a). About Confucius Institute/Classroom. Hanban website. Retrieved from http://www.hanban.org/confuciousinstitutes/node_109 61.htm [Google Scholar]. 
[17]. Jabeen, F. (2019). The perpetuation of colonial legacy: Uncovering internal orientalism in the form of English supremacy in Pakistan. Journal of Multilingual and Multicultural Development, 41(5), 432-443.

https://doi.org/10.1080/01434632.2019.1653303

[18]. Jakhar, P. (2018, February 28). Reality check: Is Chinese an official language in Pakistan? BBC News. https://www.google.com/amp/s/www.bbc.com/news/ world-asia-43158523.amp

[19]. Jiang, X., \& Cohen, A. D. (2012). A critical review of research on strategies in learning Chinese as both a second and foreign language. Studies in Second Language Learning and Teaching, 2(1), 9. https://doi.org/10.14746/ssllt.2012.2.1.2

[20]. Liu, X. (2019). So similar, so different, so Chinese: Analytical comparisons of the Confucius institute with its western counterparts. Asian Studies Review, 43(2), 256-275. https://doi.org/10.1080/10357823.2019.1584602

[21]. Ma, X., Gong, Y., Gao, X., \& Xiang, Y. (2017). undefined. Journal of Multilingual and Multicultural Development, 38(9), 815-830. https://doi.org/10.1080/01434632.2016.1268146.

Manan, S. A., David, M. K., \& Dumanig, F. P. (2016). English language teaching in Pakistan: Language policies, delusions, and solutions. Language Policy, 219-244. https://doi.org/10.1007/978-3-319-22464-0_10

[22]. Mane, D. (2013) "Improving Teaching Efficiency by Using ACTIVITY-TOOL for MBA Students: Innovative Teaching Methodology", IARS' International Research Journal. Victoria, Australia, 3(2). doi: 10.51611/iars.irj.v3i2.2013.31.

[23]. Melvin, O. (2020). Clarifying the Conceptualization of Empire: Is China's Belt and Road Initiative an Attempt at Empire? [Master's thesis https://egrove.olemiss.edu/hon_thesis/1486/

[24]. NAQVI, S. S. (2017). 'Urdu imperialism' in Pakistan: Reality or myth. IJASOS- International E-journal of Advances in Social Sciences, 387-390. https://doi.org/10.18769/ijasos.336558

[25]. Nordquist, R. (2019). What is linguistic imperialism and how does it affect society? ThoughtCo. Retrieved July 1, 2021, from https://www.thoughtco.com/whatis-linguistic-imperialism-1691126

[26]. Paradise, J. F. (2009). China and international harmony: The role of Confucius institutes in bolstering Beijing's soft power. Asian Survey, 49(4), 647-669. https://doi.org/10.1525/as.2009.49.4.647

[27]. Phillipson, R. (1992). undefined. Oxford University Press.
[28]. Qingpu, Z. (2019). undefined. Bulletin of Concerned Asian Scholars, 23(4), 57-64. https://doi.org/10.1080/14672715.1991.10413143

[29]. Reeves, J. (2018). Imperialism and the Middle Kingdom: The Xi Jinping administration's peripheral diplomacy with developing states. Third World Quarterly, 39(5), 976-998. https://doi.org/10.1080/01436597.2018.1447376

[30]. Smith, M. D., \& Donghwan, K. (2015). English \& Linguistic Imperialism: A Korean Perspective in the Age of Globalization. The Journal of Mirae English Language and Literature, 20(2), 331-350.

[31]. Sparks, C. (2014). Deconstructing the Brics. International Journal of Communication, 8, 392-418.

[32]. Sparks, C. (2018). undefined. Global Media and China, 3(2), 92-99. https://doi.org/10.1177/2059436418778935

[33]. The Uyghur Human Rights Project. (2019). The Uyghur Human Rights Report. Google. Retrieved June 30, 2021, from https://www.google.com/url?sa=t\&source=web\&rct=j \&url=https://www.state.gov/reports/2019-countryreports-on-human-rightspractices/china/\%23: :text\%3DThe\%2520Uyghur\%2 520Human\%2520Rights\%2520Project,Uighur\%2520 scholars\%2520and\%2520cultural\%2520icons.\%26tex t\%3DFive $\% 2520$ intellectuals $\% 2520$ identified $\% 2520 \mathrm{i}$ $\mathrm{n} \% 2520$ the,camp\%2520or\%2520shortly\%2520after\% 2520release.\&ved=2ahUKEwjqxsSezr_xAhWLz4UK HZ_nCGEQFjABegQIBBAF\&usg=AOvVaw1IYMh SF8yNtpphLQEcX-0Q

[34]. Wenfeng, W., \& Gao, X. (2008). English language education in China: A review of selected research. Journal of Multilingual and Multicultural Development, $\quad 29(5), \quad 380$. https://doi.org/10.2167/jmmd600.0.

[35]. Xie, T., \& Special for CNN. (2014, October 21). China guilty of cultural imperialism? CNN. https://edition.cnn.com/2014/10/21/opinion/chinaconfucius/index.html

[36]. Xinhua. (2019). Pakistani students show keen interest in learning Chinese language - Xinhua | English.news.cn. 新华网_让新闻离你更近. https://www.xinhuanet.com/english/201908/28/c_138345891.htm

[37]. Zhao, H., \& Huang, J. (2010). China's policy of Chinese as a foreign language and the use of overseas Confucius institutes. Educational Research for Policy and Practice, 9(2), 127-142. https://doi.org/10.1007/s10671-009-9078-1. 


\section{Manuscript Processing Footprints}

\section{A. Journal Volume/Issue Details}

This manuscript it published in Vol. 12 No. 012022 issue of IARS' International Research Journal (I'IRJ).

This is a Peer Reviewed (Refereed) International Journal published by IARS' Press Australia (International Association of Research Scholars) The Volume/Issue is a regular issue of the journal published in February 2022 Available at: https://researth.iars.info/index.php/curie.

\section{B. Copyright, License, and Publishing Rights}

- IARS' Press Australia (International Association of Research Scholars) respects the rights of the authors of research content published with IARS' International Research Journal. The "First Publication Rights" (FPR) to the original work accepted for publication at IARS' International Research Journal is granted to the Publisher of the Journal but copyright for all work published in the journal is retained by the author(s). Works published in the Journal is distributed under a Creative Commons Attribution 4.0 International License (CC BY 4.0). (This license lets others distribute, remix, adapt, and build upon your work, even commercially, as long as they credit you for the original creation. This is the most accommodating of licenses offered. Recommended for maximum dissemination and use of licensed materials.)

- After publishing the content with IARS' International Research Journal, the author holds complete right on the content for its amendments and reuse in any form. IARS' International Research Journal confirms that author(s) holds the copyright of the content.

- Author(s) grant(s) permission for their work to be indexed in part/full form in commercial and non-commercial indexes. Author(s) grant(s) permission for their work to be harvested in part/full form in commercial and non-commercial archives and distributed through them. Author(s) grant(s) permission for their work to be translated in part/full form in any language and republished and redistributed. Author(s) may enter into separate, additional contractual agreements for the non-exclusive distribution of the published version of the work, with an acknowledgement of its initial publication in this Journal.

- It is the responsibility of the author(s) to secure all necessary copyright and/or permissions for the use of third-party content in their manuscript(s). Author(s) have declared the same at the time of submission of manuscript and 'may also be required' to provide written evidence of this permission anytime in case required for any purposes.

- Publications Ethics and other Terms and Conditions as mentioned on official website of IARS' International Research Journal

\section{Last Plagiarism Report}

SCREENED BY

$\checkmark$ iThenticate

Settings: Quotes Excluded, Bibliography Excluded

Challenges of Teaching Chinese as a Subject in an English-
dominated Region: Focus on Sindh, Pakistan
1 part - 5,840 words

Exemption / Relaxation by Editor: None

\section{Processing Track}

\begin{tabular}{|l|l|}
\hline Date of Submission & 30 January 2022 \\
\hline Date of Final Review & 27 February 2022 \\
\hline Date of Acceptance \& Schedule & 27 February 2022 \\
\hline Date of Publishing & 28 February 2022 \\
\hline
\end{tabular}

